\title{
CHARACTERISATION OF PALM PYROLIGNEOUS ACID AND ITS EFFECTIVENESS AS ANTIFUNGAL AGENT FOR OIL PALM TRUNK
}

\author{
FAZLIANA ABDUL HAMID ${ }^{1 *}$; NAHRUL HAYAWIN ZAINAL'; NUR ELIYANTI ALI OTHMAN'; \\ FATIHA ISMAIL ${ }^{1}$; NOORSHAMSIANA ABDUL WAHAB ${ }^{1}$ and ASTIMAR ABDUL AZIZ ${ }^{1}$
}

\begin{abstract}
Pyroligneous acid (PA) is a by-product from carbonisation of palm kernel shell (PKS) with more than 200 organic compounds, including phenolic and organic acids. The purpose of this study was to characterise and evaluate the effectiveness of PA to protect oil palm trunk (OPT) against fungal attack. Wood vinegar was produced at four carbonisation temperatures (i.e., $500^{\circ} \mathrm{C}, 600^{\circ} \mathrm{C}, 700^{\circ} \mathrm{C}$ and $800^{\circ} \mathrm{C}$ ). The chemical properties of PA were measured using Fourier transform infrared (FTIR) spectroscopy and gas chromatography-mass spectroscopy (GC-MS). The antifungal assay of PA from carbonisation at $600^{\circ} \mathrm{C}$ was applied on OPT against a white-rot fungus, Trametes versicolor, and a brown-rot fungus, Fomitopsis palustris. The effectiveness of PA against both fungi was evaluated by soaking OPT in the PA solution for $24 \mathrm{hr}$ at $25^{\circ} \mathrm{C}$, followed by exposure to the media containing the fungi, as stipulated in ASTM D-4455 standard. The lowest mean weight loss $(9.33 \%)$ was obtained after eight weeks of exposure. The OPT-PA-treated specimen was highly resistant to the growth of $\mathrm{T}$. versicolor. It was assumed that acid and phenolic components contributed to enhanced growth control of fungi, as indicated from the GC-MS results. The chemical compositions of PA proved that the antifungal activities could be controlled using a high concentration of PA.
\end{abstract}

\section{Keywords: brown-rot and white-rot fungi, oil palm trunk, oil palm trunk treatment, pyroligneous acid.}

Received: 19 July 2021; Accepted: 30 November 2021; Published online: 28 January 2022.

\section{INTRODUCTION}

Palm kernel shell (PKS) is one of the abundant biomass components of oil palm and more than 4 million tonnes of PKS are produced based on fresh fruit bunch processing in palm oil mills in Malaysia, and the value is expected to increase by 2020 (MPOB, 2020). PKS contains high carbon content with a high density of $0.6 \mathrm{~g} \mathrm{~cm}^{-3}$ and a tough structure due to the high composition of lignin and carbon (Nahrul Hayawin et al., 2018). PKS is currently used as a combustion boiler

\footnotetext{
Malaysian Palm Oil Board,

6 Persiaran Institusi, Bandar Baru Bangi,

43000 Kajang, Selangor, Malaysia.

* Corresponding author e-mail: fazliana@mpob.gov.my
}

fuel with very limited efficiency. The current practice produces oil palm charcoal and activated carbon in a two-step process (i.e., carbonisation, followed by activation at high temperatures). This method requires high energy usage and extended duration, and it is also uneconomical (Rashidi et al., 2014). Nahrul Hayawin et al. (2018) developed a system of simultaneous carbonisation-activation to produce charcoal and activated carbon. This system also produced by-products (e.g., PA, tar and gases) that were condensed and trapped in the cold traps.

PA also known as wood vinegar, has a yellowish or dark brown colour with acidic $\mathrm{pH}$. The acid originates from a complex highly oxygenated aqueous liquid fraction obtained from the condensation of carbonised products or 
slow pyrolysis of wood and other lignocellulosic raw materials in the absence or limited oxygen (Zheng et al., 2018). The heavier fraction called wood tar decanted at the bottom of the container and separates from PA after some days, even a few months. PA comprises a high amount of water $(10 \%-20 \%)$, a mixture of carboxylic acids with acetic acid as the major compound (10\%), phenols and derivatives, aldehydes, and pyrolytic lignin. The major compounds obtained in pyroligneous extract include formic acid, acetic acid, propionic and valeric acids; methanol, butanol, and amylic alcohol; phenol, cresols, guaiacol, and syringol derivatives; and organic compounds (e.g., formaldehyde, acetone, furfural and valerolactone) (de Souza et al., 2017; Lee et al., 2011).

The production of PA from PKS has gained interest due to high lignin compounds that are correlated to the yield of phenolic compounds (Seri Elyanie et al., 2021). Furthermore, PA has broad applications as antimicrobial, antioxidant, antiinflammatory, soil enhancer, coagulant for natural rubber, and termiticidal and pesticidal agents. In addition, it is a source of valuable chemicals and smoky flavour for food (Mathew and Zakaria, 2015). PA has been used as an alternative medicine to promote greater body healing in Asian countries, such as China, Korea and Japan (Theapparat et al., 2018). The effectiveness and characteristics of PA may vary slightly depending on its chemical composition, which can be affected by different parameters, such as duration, heating rate, temperature, particle size and biomass feedstock used (Fačkovcová et al., 2020).

The phenolic and acid compounds obtained in PA have the potential as a source of valuable chemicals for wood preservation against biological degradation (Lee et al., 2011). According to Mohan et al. (2008), PA can be used as a preservative for timber in wet conditions. There are very few studies being conducted on the potential of bioactive compounds from PKS, particularly PA. Furthermore, the utilisation of PA in commercial products for protecting wood against fungal attack is still limited.

PA was obtained by Nahrul Hayawin et al. (2018) in the production of charcoal and activated carbon from oil PKS using a two-in-one activation process, which was conducted simultaneously in the same instrument. It is the most economically viable process with lower production costs than conventional processes. The PA from this carbonisation process can be used in the biopreservation of oil palm biomass during storage. This research aims to characterise the chemical composition of PA derived from PKS and to evaluate the effectiveness of PA for oil palm trunk (OPT) treatment against fungal attack under laboratory conditions.

\section{MATERIALS AND METHODS}

\section{Materials}

Raw PKS was obtained from Ulu Kanchong Palm Oil Factory, Ulu Kanchong Estate, Negeri Sembilan, Malaysia. Carbonisation was performed according to the methods described in Nahrul Hayawin et al. (2018). Raw PKS was carbonised at different temperatures (i.e., $500^{\circ} \mathrm{C}, 600^{\circ} \mathrm{C}, 700^{\circ} \mathrm{C}$ and $800^{\circ} \mathrm{C}$ ).

\section{Methods}

Collection of PA from charcoal production. Approximately $3 \mathrm{~kg}$ of PKS per batch was carbonised using a double-insulated carbonisation-activation system for 2-3 hr. The details of the experimental setup were referred to the system developed by Nahrul Hayawin et al. (2018). The smoke released during the process was transported via a pipe at the bottom of the reactor to a condensation unit with the assistance of an exhaust fan. Condensed gases that passed through the condenser were collected as wood vinegar. The operating system was controlled automatically using a locally fabricated programmable logic controller (PLC) (Imetronic Sdn. Bhd). The collected wood vinegar was filtered to remove dust and tar from the liquid.

Physical and chemical properties of pyroligneous acid. The $\mathrm{pH}$ value and density of PA were measured by a $\mathrm{pH}$ meter (Sartorius) and a pycnometer (Mettler Toledo), respectively. The chemical component of PA produced at different temperatures was analysed using Fourier transform infrared (FTIR) spectroscopy (TG-IR Hypernation System, PerkinElmer, USA) and gas chromatography-mass spectroscopy (GC-MS) (Agilent 7890, USA). The FTIR analysis was performed by dripping $1 \mathrm{~mL}$ of liquid PA onto the liquid sample holder. The IR spectrum was recorded in the wavelength range of 4000-400 $\mathrm{cm}^{-1}$ with a resolution of $4 \mathrm{~cm}^{-1}$ and four scans per sample using a Perkin-Elmer Spectrum (Perkin-Elmer, Waltham, MA, USA). PA waste needs to be pre-treated prior to GC-MS analysis (Wei et al., 2010). Therefore, $10 \mathrm{~mL}$ of PA was washed by $3 \mathrm{~mL}$ of diethyl ether six times, in which $30 \%$ (v/v) of ether was used each time. The remaining ether in the liquid at the bottom layer was removed. About $0.1 \mathrm{~g}$ of magnesium sulphate was added to the sample, which was then purged with nitrogen for $20 \mathrm{~min}$ to remove excess solvent. The GC-MS method was described in Oramahi et al. (2018).

Decay fungi test. Decay resistance test for determining antifungal activity on OPT was carried out according to ASTM D-2017 (2008) involving two types of fungi: brown-rot fungi (Fomitopsis palustris) 
and white-rot fungi (Trametes versicolor) (ASTM, 1978). Both fungi were grown on potato dextrose agar (PDA) and incubated in a sealed petri dish using an incubator at $27^{\circ} \mathrm{C}$ with $70 \%$ environment humidity. The test was carried out for a period of eight weeks with standard weekly observation until fungi started to grow on the test OPT block.

The fungi used in the decay resistance test (F. palustris and T. versicolor) were supplied by MyEnzyme Sdn. Bhd. The isolation of fungi was repeated several times until pure fungi were obtained. The fungal resistance test was carried out according to ASTM D-4445 using OPT samples (length, width, and thickness of 5, 20 and $10 \mathrm{~mm}$, respectively) treated with $\mathrm{PA}$, which were placed onto the PDA inoculated with brown-rot and whiterot fungi (ASTM, 2003; Khoirun Nisa et al., 2016). Untreated OPT samples were used as a control for both experiments and eight pieces of OPT samples were used for each treatment including control sample. All treated samples were soaked at $25^{\circ} \mathrm{C}$ in selected PA for $24 \mathrm{hr}$. After that, the treated OPT samples were removed and excess solution was washed off and allowed to dry to constant weight for three weeks at room temperature. The samples were sterilised at $100^{\circ} \mathrm{C}$ after the OPT samples reached a constant weight, weighed, and exposed to PDA inoculated with both fungi in a sealed petri dish at $27^{\circ} \mathrm{C}$ for eight weeks. After eight weeks of incubation, the surface covered with fungi was removed. The samples were then dried at $105^{\circ} \mathrm{C}$ to a constant weight. Mass loss (ML) was determined for the control and impregnated wood blocks gravimetrically using the following equation:

$$
\mathrm{ML}=\frac{\mathrm{mdw} 1-\mathrm{m} \mathrm{dw} 2}{\mathrm{mdw} 1} \times 100 \%
$$

where $\mathrm{m} \mathrm{dw} 1(\mathrm{~g})$ is the mass of the wood block before being exposed to the fungi and $\mathrm{m} \mathrm{dw} 2(\mathrm{~g})$ is the mass of the decayed wood block.

Statistical analysis. The statistical significant test (ANOVA single factor, Fischer LSD test) was conducted on the PA treatment on the OPT test block.

\section{RESULTS AND DISCUSSION}

\section{Effect of Carbonisation Temperature on PA Yield}

The PA yield was $30 \%(\mathrm{w} / \mathrm{v})$ at $500^{\circ} \mathrm{C}$ and achieved the maximum value of $58 \%$ at $600^{\circ} \mathrm{C}$. After that, the yield decreased at $650^{\circ} \mathrm{C}$ (Figure 1). The increment in PA yield is mainly attributed to the decomposition of cellulose and lignin components, which are correlated to the major components in PKS. Besides the decomposition of cellulose and lignin, many volatile materials also decomposed at this temperature range, resulting in the release of several gases, such as carbon monoxide, carbon dioxide, and methane. The results also showed that the yield of PA decreased at the temperature range of $700^{\circ} \mathrm{C}-800^{\circ} \mathrm{C}$. Less PA was produced and more tar was formed due to the decomposition of lignin at high temperatures. Another explanation is the secondary degradation of some ingredients found in PA at higher carbonisation temperatures as they are thermally unstable products (Demiral and Ayan, 2011).

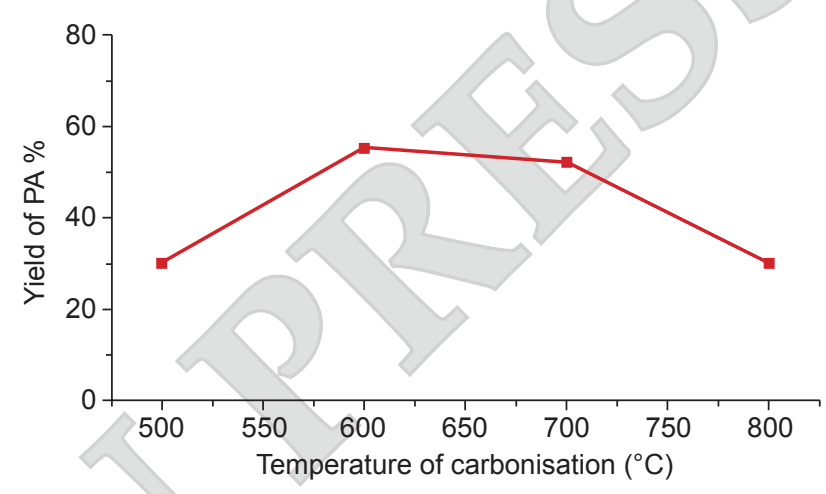

Figure 1. Amount of PA yield vs. carbonisation temperature.

\section{Chemical Properties of Pyroligneous Acid}

The chemical properties of PA were analysed and reported based on the highest yield at $600^{\circ} \mathrm{C}$ (Table 1). Based on the observation of carbonised PKS, the PA was yellowish-brown with a density of approximately $1.021 \mathrm{~g} / \mathrm{mL}$. The FTIR spectra of PA at different temperatures are shown in Figure 2. The broad bands of the hydroxyl stretching and carbonyl groups at $3327 \mathrm{~cm}^{-1}$ and $1637 \mathrm{~cm}^{-1}$, respectively, indicate the presence of water and other polymeric $\mathrm{O}-\mathrm{H}$ in $\mathrm{PA}$. The $\mathrm{C}-\mathrm{H}$ stretching from the methylene group, C-O ether, and aromatic compounds are overlapping absorption bands at $1637 \mathrm{~cm}^{-1}$. The spectrum also showed the overlapping peaks of $\mathrm{C}-\mathrm{H}$, indicating the presence of alkanes in the PA group at the range of $3200-2800 \mathrm{~cm}^{-1}$ (Tsai et al., 2007).

TABLE 1. PHYSICAL PROPERTIES OF PYROLIGNEOUS ACID

\begin{tabular}{lc}
\hline Parameter & Result \\
\hline $\mathrm{pH}$ & 3.5 \\
Density & $1.021 \mathrm{~g} / \mathrm{mL}$ \\
Colour & Yellowish-brown \\
\hline
\end{tabular}

The decomposition of cellulose and hemicellulose produced several products, such as carboxylic acids, ketones, phenols, aldehydes and alcohols. The band at $1800-1600 \mathrm{~cm}^{-1}$ can be 
attributed to $\mathrm{C}=\mathrm{O}$, which represents the existence of ketones, aldehydes, and carboxylic acids. Meanwhile, the band at $2122 \mathrm{~cm}^{-1}$ belongs to $C=C$ stretching vibration, indicating the presence of alkanes and aromatic compounds in PA.

Chemical characterisation using GC-MS identified about 20 main components in the PA produced at $600^{\circ} \mathrm{C}$, including their derivatives (Table 2). The major compounds obtained were carboxylic acids, phenols, ketones, aldehydes, alcohols, alkenes, furans, and esters with other derivatives, such as acetic acid (43.5\%), glyceraldehyde $(16.90 \%)$, and propanoic acid $(13.98 \%)$. The higher amount of acid in PA is due to the decomposition of hemicellulose and volatile matter during carbonisation at $250^{\circ} \mathrm{C}-350^{\circ} \mathrm{C}$
(Demirbas, 2007). The degradation of hemicellulose and cellulose at $250^{\circ} \mathrm{C}-275^{\circ} \mathrm{C}$ will lead to the production of light oxygenates, acetic acid, furfural and water. The thermal degradation of cellulose occurred in two stages, depending on the pyrolysis temperature, where some cellulose degrades below $320^{\circ} \mathrm{C}$ and the remaining cellulose degrades at higher temperatures (Wang et al., 2021). Phenolic compound $(12.48 \%)$ was obtained from the decomposition of lignin at $500^{\circ} \mathrm{C}-600^{\circ} \mathrm{C}$, which is relatively high, followed by furans, esters, alkanes and ketones. The decomposition of lignin occurs at intermediate degradation temperatures from $250^{\circ} \mathrm{C}$ to $500^{\circ} \mathrm{C}$, producing various hydroxyl and methoxy substituted phenylpropane compounds (Theapparat et al., 2018).

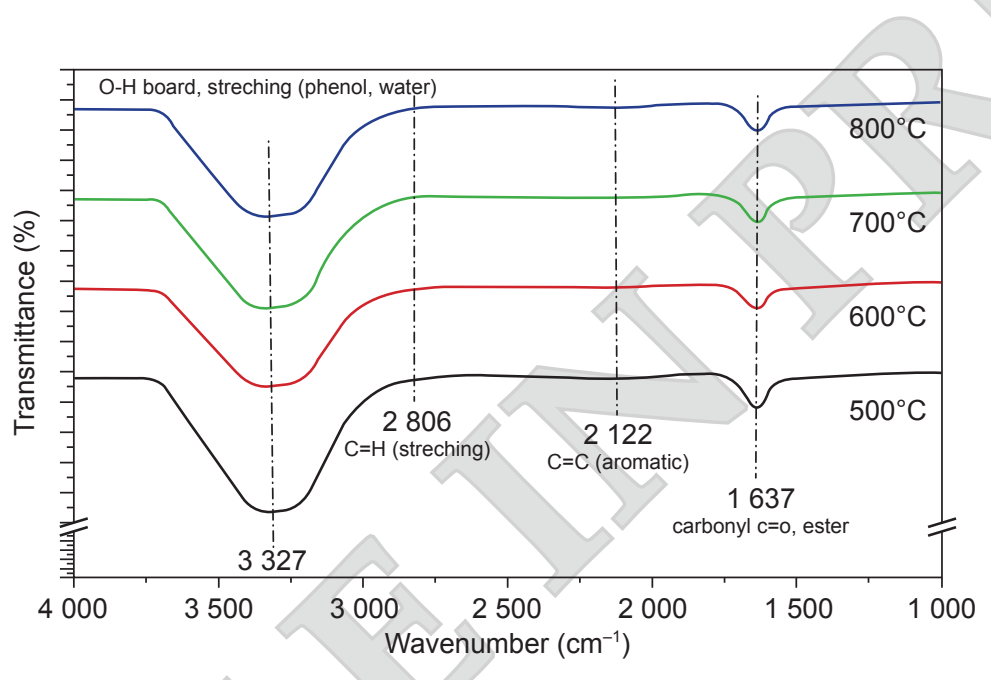

Figure 2. FTIR spectrum of PA produced at different temperature.

TABLE 2. MAIN COMPONENTS IN THE PALM BASED PYROLIGNEOUS ACID AT $600^{\circ} \mathrm{C}$

\begin{tabular}{|c|c|c|c|}
\hline Chemical category & $\begin{array}{l}\text { ention time } \\
\text { (min) }\end{array}$ & Compounds & $\begin{array}{c}\text { Relative contents } \\
\qquad \%)\end{array}$ \\
\hline Nitrogenated and derivates & 7.44 & Pyridine & 9.05 \\
\hline \multirow[t]{4}{*}{ Organics acid } & 24.54 & Acetic acid & 43.59 \\
\hline & 10.56 & Formic acid & 0.81 \\
\hline & 11.65 & Propanoic acid & 13.98 \\
\hline & 13.77 & 4-hydroxybutanoic acid & 4.92 \\
\hline \multirow{3}{*}{$\begin{array}{l}\text { Aldehyde } \\
\text { Phenol and derivatives }\end{array}$} & 9.07 & Glyceraldehyde & 16.90 \\
\hline & 29.05 & 3-methylpentanal & 0.21 \\
\hline & 20.22 & Phenol & 12.48 \\
\hline \multirow[t]{5}{*}{ Furan and derivatives } & & Tetrahydro-3-furanol & 4.92 \\
\hline & 17.79 & Tetrahyrdo-2H-pyran-2-one & 4.25 \\
\hline & 33.64 & $2(5 \mathrm{H})$ furanone & 0.57 \\
\hline & & 4-methyl -5H-furan -2 -one & 0.26 \\
\hline & 35.35 & 4 H-pyran -4 one & 0.24 \\
\hline Alkanes & 22.62 & Ethenylmethylene cyclopropane & 0.09 \\
\hline \multirow[t]{3}{*}{ Esters } & 10.9 & Cyclohexan-1,4,5-triol 3-one -1-carboxylic acid & 1.66 \\
\hline & 19.88 & Hexadecanoic acid , 2 (octadecycloxy)ethyl ester & 0.79 \\
\hline & 22.38 & Hexadecanoic acid, 1-hydroxymethyl)1-2-ethanediyl ester & 1.05 \\
\hline Ketones & 13.80 & Butyrolactone & 5.79 \\
\hline
\end{tabular}


Antifungal Activity of Palm Pyroligneous Acid on Oil Palm Trunk Treatment

Figure 3 shows the fungal colonisation obtained on the surface of OPT test blocks after eight weeks of exposure to white-rot and brown-rot fungi. All the OPT test blocks treated with PA showed promising results against fungal growth compared to the untreated OPT samples. The highest antifungal activity of PA on white-rot fungi is probably due to the presence of acid and phenolic compounds in PA. The phenol content in PA is responsible for antifungal activity (Oramahi et al., 2018). As the carbonisation temperature increased, phenolic compounds were obtained from the decomposition of lignin at $300^{\circ} \mathrm{C}-500^{\circ} \mathrm{C}$ of pyrolysis temperature, and this approach is effective for preventing fungal or mould growth (Lee et al., 2011).

After five days of exposure, all OPT test blocks treated with PA showed that less than $10 \%$ of the surface area was covered with brown-rot and whiterot fungi compared to non-treated OPT samples. The untreated OPT test blocks were used as control sets. The formation of brown-rot fungi could be observed after one week of treatment. Almost $75 \%$ of the surface area of the OPT-PA test blocks was covered by brown-rot fungi after 30 days of exposure. The increase in water activity would enhance the growth of fungi (Khairon Nisa et al., 2016). Surprisingly, the treated OPT test blocks exposed to white-rot fungi showed less than $10 \%$ surface coverage after 30 days of exposure. The resistance of wood against fungi might be due to the inhibition of

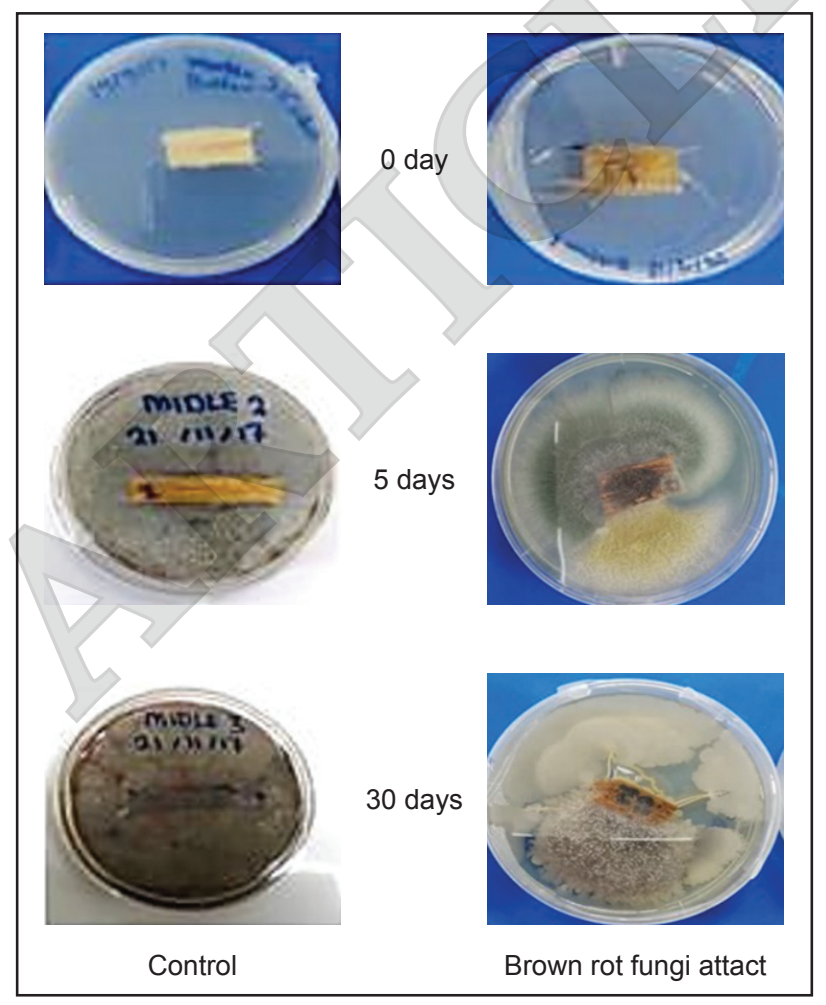

enzymatic activity by wood vinegar (Oramahi et al., 2018). Temperature is the most important factor in the characterisation of the components and the effectiveness of PA in controlling wood degradation (Nakai et al., 2007). However, it must be considered that the experiments are soil-free bioassays.

The effectiveness of the treatment was observed based on the resistance to rot biodegradation without ground contact. The wood exposed to the outdoor testing without any treatment showed less resistance to fungi attack, which was not comparable to the short-term durability in the laboratory testing. With the exposure to ground contact, the deterioration occurred rapidly in the shade (Brischke and MeyerVeltrup, 2016). The phenolic and acid components available in PA would be able to treat the white-rot fungi but were less inhibitory to the brown-rot fungi. The soaking method is not suitable to prevent fungal attack. Improved methods should be developed to enhance the prevention of OPT from fungal growth during storage and before further process.

\section{Decay Fungi Test}

There was a significant difference in the mean weight loss value of the three different OPT test blocks (Figure 3). The untreated OPT sample recorded the highest mean weight loss value of $37.14 \%$, followed by OPT-PA BR $(21.68 \%)$. The treated OPT-PA sample exposed to white-rot fungi indicated the lowest mean weight loss of $9.33 \%$. Resistance classes are based on the mean weight value according to the standard ASTM D-2017-71

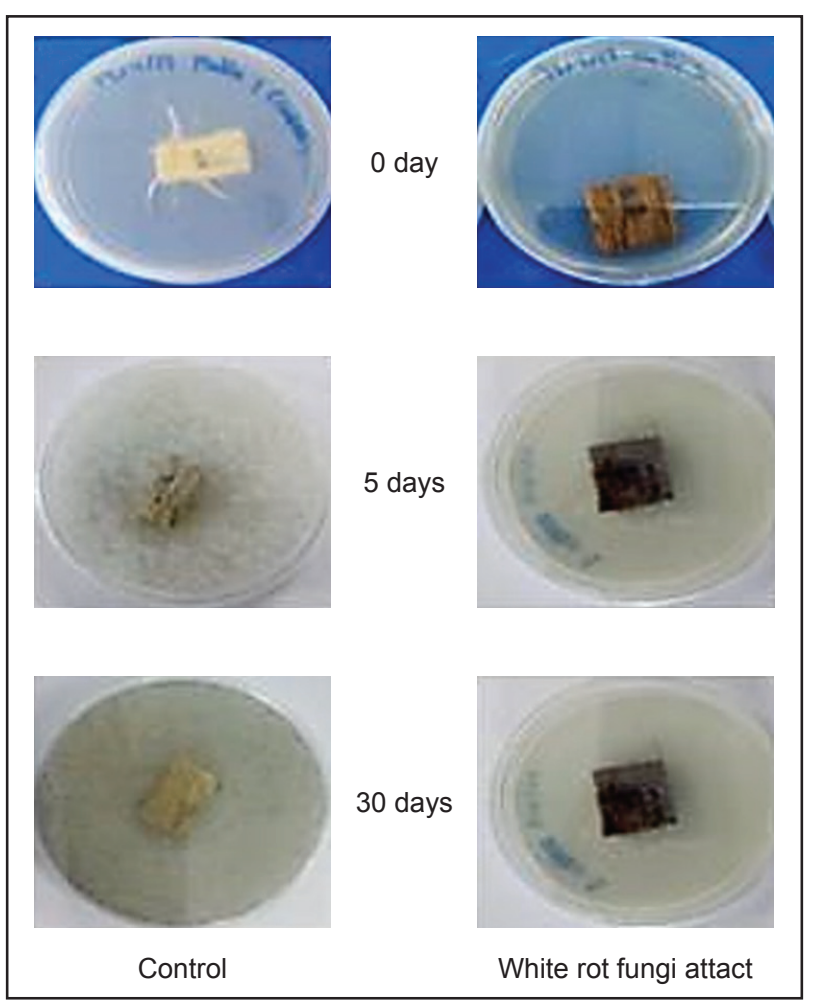

Figure 3. OPT control and OPT-PA exposed to brown and white rot fungi. 


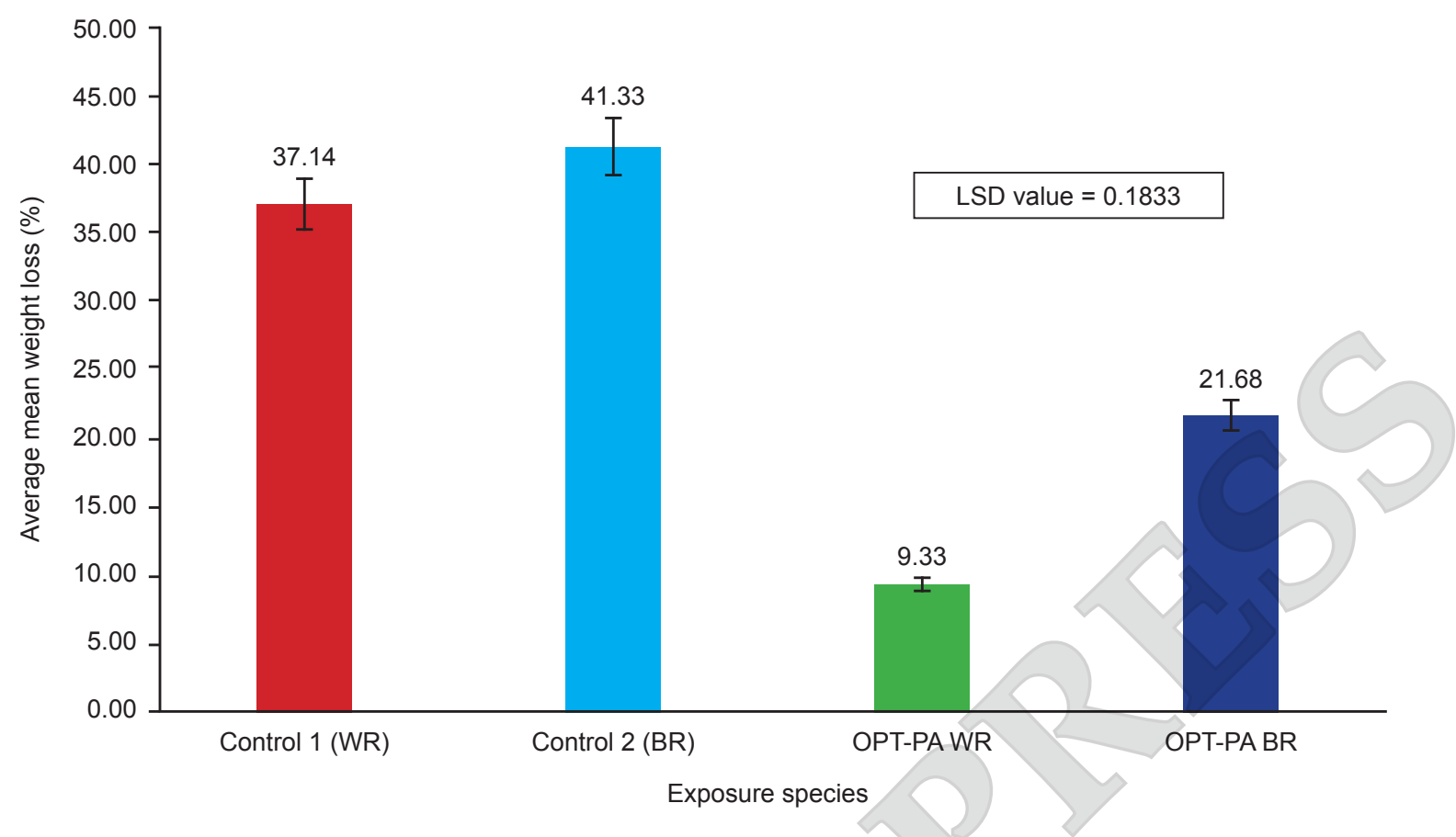

Figure 4. Mean weight loss of untreated and treated OPT-PA against white-rot (WR) and brown-rot (BR) fungi.

(ASTM, 1978). The OPT-PA treated blocks were the most resistant to fungal attack due to the blocks' low mean weight loss value (Table 3). The exposure of the treated OPT to brown-rot fungi was categorised as resistance class only. Meanwhile, the untreated OPT sample indicated the highest mean weight loss and showed moderate resistance against both fungi. The details of resistance classes can be referred to Table 4 . The moisture content above $25 \%$ and the temperature between $20^{\circ} \mathrm{C}$ and $35^{\circ} \mathrm{C}$ are the factors influencing the decay of wood by fungi (Andrade et al., 2012).

TABLE 3. MEAN WEIGHT LOSS AND RESISTANT CLASS OF UNTREATED AND TREATED OPT TEST BLOCKS AGAINST WHITE AND BROWN ROT FUNGI AFTER 8 WEEKS

\begin{tabular}{lcc}
\hline Sample & Mass loss (\%) & Class resistant \\
\hline Untreated OPT & 37.14 & Moderate resistant \\
OPT-PA BR & 21.68 & Resistant \\
OPT-PA WR & 9.33 & Highly resistant \\
\hline
\end{tabular}

TABLE 4. CLASS OF DECAY-RESISTANT

\begin{tabular}{lcc}
\hline Class of resistance & $\begin{array}{c}\text { Mass loss } \\
(\mathbf{\%})\end{array}$ & $\begin{array}{c}\text { Residual loss } \\
\mathbf{( \% )}\end{array}$ \\
\hline Highly resistant (HR) & $0-10$ & $90-100$ \\
Resistant (R) & $11-24$ & $76-89$ \\
Moderate Resistant (MR) & $25-44$ & $56-75$ \\
Not resistant (NR) & $>45$ & $>55$ \\
\hline
\end{tabular}

Source: ASTM D-2017-71, ASTM (1978); Wong et al., (2012).
In wood delignification, lignin and hemicellulose are most degraded. This can be observed from the mean weight loss value of the untreated and treated OPT samples after 30 days of exposure to both fungi. The results showed that the decay process was inhibited by the fungicidal agent if the wood is not protected well. The hydrolytic activities and enzymes produced by both fungi are vital in the degradation of chemical components of wood (Andrade et al., 2012). The degradation of wood structure, especially lignin and carbohydrate, is due to white-rot fungi, whereas brown-rot fungi only attack carbohydrates (Pandey and Nagveni, 2007). In general, white-rot and brown-rot fungi require 60 and 120-150 days for the degradation process, respectively. The high acid and phenolic compounds in PA act as preservatives, which are suitable for protecting OPT by enhancing durability towards decay, and this is in agreement with Edi Suhaimi et al. (2013).

\section{CONCLUSION}

A high yield of PA (55\%) was successfully produced at $600^{\circ} \mathrm{C}$. As the carbonisation temperature increased, the yield of PA decreased due to the production of tar. The results highlighted the potential of PA derived from PKS as an antifungal agent for OPT treatment during storage. The PA showed good antifungal properties, which can be attributed to the presence of phenolic and carboxylic acids, such as acetic acid and propanoic acid, as 
well as aldehydes and ketones. The treated OPT-PA samples demonstrated high resistance against the degradation of white-rot fungi even for 30 days of exposure. An improved method to protect OPT and the use of PA as a biopreservative can be effective for OPT treatment during storage.

\section{ACKNOWLEDGEMENT}

The authors would like to thank the support from the MPOB for financial support in completing this project.

\section{REFERENCES}

Andrade, F A; Calonego, F W; Severo, E T D and Furtado, E L (2012). Selection of fungi for accelerated decay in stumps of Eucalyptus spp. Bioresour. Technol., 110: 456-461. DOI: 10.1016/j. biortech.2012.01.069.

ASTM (1978). Standard Method of Accelerated Laboratory Test of Natural Decay Resistance of Wood. American Society for Testing and Material ASTM D2017-71. Philadelphia. p. 638.

ASTM (2003). Standard Test Method for Fungicides for Controlling Sapstain and Mold on Unseasonable Lumber (Laboratory Method). American Society for Testing and Material. USA. p. 4.

Brischke, C and Meyer-Veltrup, L (2016). Performance of thermally modified wood during 14 years of outdoor exposure. Int. Wood Prod. J., 7(2): 89-95.

Demiral, I and Ayan, E A (2011). Pyrolysis of grape bagasse: Effect of pyrolysis conditions on the product yields and characterization of the liquid product. Bioresour. Technol., 102: 3946-3951. DOI: 10.1016/j.biortech.2010.11.077.

Demirbas, A (2007). The influence of temperature on the yields of compounds existing in bio-oils obtained from biomass samples via pyrolysis. Fuel Process. Technol., 88: 591-597. DOI: 10.1016/j. fuproc.2007.01.010.

de Souza Araujo, E; Pimenta, A S; Feijo, F M C; Castro, R V O; Fasciotti, M; Monteiro, T V C and de Lima, K M G (2017). Antibacterial and antifungal activities of pyroligneous acid from wood of Eucalyptus urograndis and Mimosa tenuiflora. J. Appl. Microbiol., 124(1): 85-96. DOI: 10.1111/jam.13626.

Edi Suhaimi Bakar; Hao, J; Ashaari, Z and Choo, A C Y (2013). Durability of phenolic-resin-treated oil palm wood against subterranean termites a white-rot fungus. Int. Biodeter. Biodegr., 85: 126-130.

Fačkovcová, Z; Vannini, A; Monaci, F; Grattacaso, M; Paoli, L and Loppi, S (2020). Effects of wood distillate (pyroligneous acid) on sensitive bioindicators (lichen and moss). Ecotoxicol. Environ. Saf., 204: 111117. DOI: 10.1016/j.ecoenv.2020.111117.

Khoirun Nisa, M; Maizatulakmal, Y; Siti Hajar, M S; Nurul Husna, R; Chai, B M, Nurul Farhana, M; Sulaiman, N; Salmiah, U and Zainul Akmar, Z (2016). Evaluation on efficiency of pyroligneous acid from palm kernel shell as antifungal and solid pineapple biomass as antibacterial and plant growth promoter. Sains Malays., 45(10): 1423-1434.

Lee, S H; H'ng, P S; Chow, M J; Sajap, A S; Tey, B T; Salmiah, U and Sun, Y L (2011). Effectiveness of pyroligneous acids from vapour released in charcoal industry against biodegradable agent under laboratory condition. J. Appl. Sci., 11(24): 3848-3853.

Mathew, S and Zakaria, Z A (2015). Pyroligneous acid-the smoky acidic liquid from palm biomass. Appl.Microbiol. Biotechnol., 99: 611-622. DOI: 10.1007/ s00253-014-6242-1.

Mohan, D; Shi, J; Nicholas, D D; Pittman Jr, C U; Steele, P H and Cooper, J E (2008). Fungicidal values of bio-oils and their lignin-rich fractions obtained from wood/bark fast pyrolysis. Chemosphere, 71: 456-465.

MPOB (2020). MPOB Statistic 2020. https://bepi. mpob.gov.my/index.php/en/area/area-2020 / oilpalm-planted-area-as-at-dec-2020, assessed on 14 September 2021.

Nahrul Hayawin, Z; Astimar, A A; Juferi, I; Nor Faizah, J; Ropandi, M; Mohamad Faizal, I; Mohd Ali, H; Ezyana, K B; Nur Sulihatimarsyila, A W and Suraini, A A (2018). Carbonisation-activation of oil palm kernel shell to produce activated carbon and methylene blue adsorption kinetics. J. Oil Palm Res., 30(3): 495-502. DOI: 10.21894/ jopr.2018.0039.

Nakai, T; Kartal, S N; Hata, T and Imamura, Y (2007). Chemical characterization of pyrolysis liquids of wood-based composites and evaluation of their bio-efficiency. Build. Environ., 42: 1236-1241. DOI: 10.1016/j.buildenv.2005.11.022.

Oramahi, H A; Yoshimura, T; Farah Diba; Dina Setyawati and Nurhaida (2018). Antifungal and antitermitic activities of wood vinegar from oil 
palm trunk. J. Wood Sci., 64: DOI: 10.1007/s10086018-1703-2.

Pandey, K K and Nagveni, H C (2007). Rapid characterisation of brown and white rot degraded chir pine and rubberwood by FTIR spectroscopy. Holz Roh Werkst, 65(6): 477-481. DOI: 10.1007/ s00107-007-0181-9.

Rashidi, N A; Yusup, S; Borhan, A and Loong, L H (2014). Experimental and modelling studies of carbon dioxide adsorption by porous biomass derived activated carbon. Clean Tech. Environ. Policy, 16: 1353-1361. DOI: 10.1007/ s10098-014-0788-6.

Seri Elyanie Zulkifli; Mohd Amir Asyraf Mohd Hamzah; Maizatulakmal Yahayu; Astimar Abd Aziz; Najihah Mohd Hashim and Zainul Akmar Zakaria (2021). Optimisation of microwaveassisted production of acid condensate from palm kernel shell and its biological activities. Biomass Conv. Bioref. DOI: 10.1007/s13399-021-01631-6.

Theapparat, Y; Chandumpai, A and Faroongsarng, D (2018). Physicochemistry and utilization of wood vinegar from carbonization of tropical biomass waste. Tropical Forests - New Edition (Sudarshana, P; Nageswara-Rao and Soneji, J $\mathrm{R}$ eds.). IntechOpen. p. 163-183. DOI: 10.5772/ intechopen.77380.
Tsai, W T; Lee, M K and Chang, Y M (2007). Fast pyrolysis of rice husk: Product yields and compositions. Bioresour. Technol., 98: 22-28. DOI: 10.016/j.biortech.2005.12.005.

Wang, J; Minami, E; Asmadi, M and Kawamoto, $\mathrm{H}$ (2021). Effect of delignification on thermal degradation reactivities of hemicellulose and cellulose in wood cell walls. J. Wood Sci., 67: 19. DOI: 10.1186/s10086-021-01952-0.

Wei, Q; Ma, X and Dong, J (2010). Preparation, chemical constituents and antimicrobial activity of pyroligneous acids from walnut tree branches. J. Anal. Appl. Pyrolysis, 87: 24-28. DOI: 10.1016/j. jaap.2009.09.006.

Wong, A H H; Jem, J M E and Lai, J K (2012). Classifying white rot decay resistance of some hardwoods from Sarawak and Peninsular Malaysia and correlations with their tropical in-ground durability. The International Research Group on Wood Protection. International Union of Forest Research Organizations All Division 5 Conference. http:// ir.unimas.my/id/eprint/ 16023

Zheng, H; Sun, C; Hou, X; Wu, M; Yao, Y and Li, F (2018). Pyrolysis of Arundo donac L. to produce pyrolytic vinegar and its effect on the growth of dinoflagellate Karenia brevis. Bioresour. Technol., 247: 273-281. 